\title{
Development and Validation of User Experience-Based E-Learning Acceptance Model for Sustainable Higher Education
}

\author{
Baqar Ali Zardari ${ }^{1}$, Zahid Hussain ${ }^{1, *}$, Aijaz Ahmed Arain ${ }^{1}$ (D) Wajid H. Rizvi ${ }^{2}$ and Muhammad Saleem Vighio ${ }^{1} \mathbb{C}$ \\ 1 Faculty of Science, Quaid-e-Awam University of Engineering, Science and Technology, Nawabshah 67480, \\ Pakistan; alizardari34@quest.edu.pk (B.A.Z.); aijaz@quest.edu.pk (A.A.A.); \\ saleem.vighio@quest.edu.pk (M.S.V.) \\ 2 Institute of Business Administration, Karachi 75270, Pakistan; wrizvi@iba.edu.pk \\ * Correspondence: zhussain@quest.edu.pk
}

\section{check for} updates

Citation: Zardari, B.A.; Hussain, Z.; Arain, A.A.; Rizvi, W.H.; Vighio, M.S. Development and Validation of User Experience-Based E-Learning Acceptance Model for Sustainable Higher Education. Sustainability 2021, 13, 6201. https://doi.org/10.3390/ su13116201

Academic Editors: David

Fonseca Escudero and Mónica

Vanesa Sánchez-Sepúlveda

Received: 31 March 2021

Accepted: 27 May 2021

Published: 31 May 2021

Publisher's Note: MDPI stays neutral with regard to jurisdictional claims in published maps and institutional affiliations.

Copyright: (C) 2021 by the authors Licensee MDPI, Basel, Switzerland. This article is an open access article distributed under the terms and conditions of the Creative Commons Attribution (CC BY) license (https:/ / creativecommons.org/licenses/by/ $4.0 /)$.

\begin{abstract}
E-learning is a convenient way of learning through a portal. E-learning is being increasingly adopted in the world; however, the factors that influence the intention of users for accepting the e-learning technology have not been sufficiently explored, particularly in developing countries. Although many e-learning acceptance models do exist, the research on a user experience (UX)-based e-learning acceptance model is still lacking. As UX is one of the crucial factors for the acceptance of an e-learning portal, this research study aims to develop and validate a UX-based e-learning acceptance framework for sustainable higher education. In this connection, a web-based responsive e-learning portal for university students has been developed. The portal can be accessed from anywhere, at any time, and on any device, making the learning sustainable. The UX-based e-learning acceptance framework is developed by integrating the selected constructs of a widely accepted UX model, technology acceptance model (TAM), and four well-known constructs from various technology acceptance models. The constructs are appeal, pleasure, satisfaction, perceived ease of use, perceived usefulness, information quality, self-efficacy, social influence, benefits, and behavioral intention, which can predict the intentions of the students for acceptance of the e-learning portal. The data were collected from 650 university students using online and manual questionnaires. After data screening, 513 valid responses were further analyzed using structural equation modeling. According to the results, the framework fits the data well. The constructs satisfaction, perceived ease of use, perceived usefulness, information quality, self-efficacy, social influence, and benefits have a statistically significant effect on the behavioral intention of the students regarding the acceptance of the e-learning portal. The construct perceived ease of use has a statistical significant impact on perceived usefulness and pleasure. The construct appeal has a statistical significant impact on pleasure and satisfaction. Similarly, the construct pleasure has also a positive statistical significant impact on satisfaction. This research study contributes to the e-learning acceptance models by developing and validating the UX-based e-learning acceptance framework for sustainable higher education. The framework provides important insights for the acceptance of university based e-learning portals in the context of developing countries.
\end{abstract}

Keywords: user experience; e-learning; acceptance model; conceptual framework; sustainable higher education; structural equation modeling

\section{Introduction}

E-learning is a convenient way of learning through a portal. Due to COVID-19 and technology enhancement, e-learning becomes crucial for the students, particularly for university students. Through students' interaction, e-learning can promote collaborative learning. Information sharing between the instructor and learner is also encouraged by e-learning, while students' performance and satisfaction on learning materials are also increased through it [1,2]. At their comfort and requirements, learners can fulfill their 
needs through e-learning, while teaching-learning materials can be shared and offered in diverse formats [2]. In this connection, an e-learning portal for the university students has been developed at the Quaid-e-Awam University of Engineering, Science and Technology (QUEST), Pakistan, which is accessible at www.questelearning.com (accessed on 26 May 2021), as no formal learning management system was available in the university. The details about this portal, already published, can be accessed from [3].

The portal consists of many features, including the following [3]:

(1) Videos of the Lectures (Course-wise)

(2) Notes of the Lectures (Course-wise)

(3) MCQs of the Lectures (Course-wise)

(4) Progress of the Students in Graphs (Course-wise)

(5) Chatroom

(6) Forum

(7) FAQs

(8) Most Subscribed Courses

(9) Top Rated Courses

(10) Video Comments

(11) Video Ratings

The students can get themselves registered, and afterwards, they can subscribe to any course. They can search for any course or they can navigate to their desired course. Additional support is available to them in the form of social learning, where they can get feedback from peers and teachers through the Chatroom and Forum [3].

Based on responsive web design, the e-learning portal can be accessed from anywhere, at any time, and on any device, thus making the learning sustainable. "Responsive web design offers an efficient and practicable solution to address the plethora of different mobile devices with countless varying characteristics (screen-size, input, size, etc.)" [4]. Therefore, "through a responsive design approach, a web page adjusts itself in response to the respective screen size of a device" [4].

E-learning is being increasingly adopted in the world; however, the factors that influence the intention of users for accepting the e-learning technology have not been sufficiently explored, particularly in developing countries. Therefore, the factors should be studied that affect students' intention regarding the use of e-learning [5,6]. The technology acceptance model (TAM) is a widely accepted model for predicting the intention of the users regarding use of the technology [7]. TAM has been extended by various studies with several technologies, e.g., telemedicine services, virtual reality, and purchasing through a mobile app. A few other technology acceptance models are UTAUT [8], extended UTAUT (UTAUT2) [9], TAM2 [10], TPB [11], TRA [12], etc.

User experience (UX) is a widely explored aspect in human-computer interaction. According to ISO [13], UX is a "person's perceptions and responses resulting from the use and/or anticipated use of a product, system or service". According to Norman and Nielsen [14], "User experience encompasses all aspects of the end-user's interaction with the company, its services, and its products". According to Hassenzahl [15], UX is a combination of pragmatic and hedonic experiences; he states that "Pragmatics refers to the product's perceived ability to support the achievement of 'do-goals', such as 'making a telephone call', 'finding a book in an online bookstore', 'setting-up a webpage'. In contrast, hedonics refers to the product's perceived ability to support the achievement of 'be-goals', such as 'being competent', 'being related to others', 'being special'". Even though TAM and other technology acceptance models are robust and widely used, they lack the UX aspect. UX is one of the key factors for the acceptance of any technology, specifically, elearning. According to Harrati et al. [16], positive UX is of crucial importance for e-learning technology. Yakit and Ismailova [17] state that UX is crucial for the success of learning management systems. Many researchers have proposed UX models for measuring the UX of various technology products. A UX model has been proposed by Hassenzahl [18] that focuses on a technological product's pragmatic and hedonic characteristics that form "the 
bases for consequences, relative to a situation, including assessments of appeal, pleasure, and satisfaction" $[19,20]$. Other UX models that have been proposed are the CUBI UX model [21] and the components of user experience (CUE) model [22].

Many models related to technology acceptance exist; likewise, models for measuring UX have also been proposed but these models have been integrated very rarely $[19,23,24]$. According to the literature and to the best of our knowledge, TAM and UX models have not been integrated yet in the context of e-learning technology acceptance in developing countries. Hence, the research on the UX-based e-learning technology acceptance model is still lacking. So, we aim to fill this research gap by combining TAM and UX models. In other words, this research study aims to develop and validate a UX-based e-learning technology acceptance framework for sustainable higher education.

This article is further structured into the following sections: Section 2 describes the theoretical background and hypotheses development, while the research methodology is presented in Section 3. The results are given in Section 4. Finally, Section 5 includes the discussion and conclusion.

\section{Theoretical Background and Research Hypotheses Development}

In the present study, ten constructs have been adapted from different models. Three UX constructs have been adapted from Hassenzahl's model [18], three constructs have been adapted from TAM, and the remaining constructs have been integrated from different technology acceptance models because of their empirical replications and high explanatory power [7]. Figure 1 shows our proposed research framework, which includes perceived ease of use (PEoU), appeal (APP), pleasure (PL), satisfaction (SAT), perceived usefulness $(\mathrm{PU})$, information quality (IQ), self-efficacy (SE), social influence (SI), benefits (BEN), and behavioral intention (BI). In the present research work, $\mathrm{BI}$ is hypothesized to be affected by PEoU, PU, BEN, SAT, IQ, SE, and SI. Moreover, SAT is hypothesized to be affected by APP and PL. Additionally, PL is hypothesized to be affected by PEoU and APP; and PU is hypothesized to be affected by PEoU.

The following sub-sections give details about these constructs along with their justification and the proposed hypotheses.

\subsection{Appeal (APP)}

Hassenzahl [18] defines an appeal as, "If a product is able to trigger positive emotional reactions it is appealing". The appeal has also been defined as "the tangible aspect of the online environment that reflects the 'look and feel' or perceived attractiveness of a Website" [25]. According to Hassenzahl [18], during factor analysis, appeal is one of the highly loaded factors. Appeal is a foremost factor for the websites. So, numerous researchers tested the appeal factor in their studies. The appeal factor influences directly or indirectly the intention and increases the prediction ability of the model [26]. According to Rodríguez-Torrico et al., appeal is a positive significant determinant toward satisfaction [27]. Appeal is also tested and corroborated by Chaitanya and Gupta; they report that appeal has a significant effect on customer satisfaction [28]. In the research study of Lee et al., visual appeal has a positive effect on pleasure to use the high-technology products [29]. Chang et al. have also tested and proved that aesthetic appeal has a statistically significant effect on pleasure when using web portals [30]. Guo et al. also used aesthetic appeal in their research. They claimed that the aesthetic appeal construct has a positive influence on the pleasure of the students when using job-hunting websites [31]. Thus, hypothesis 1 and hypothesis 2 are formulated as follows:

Hypothesis 1 (H1). Appeal has a positive impact on satisfaction to use the e-learning portal.

Hypothesis 2 (H2). Appeal has a positive impact on pleasure to use the e-learning portal. 


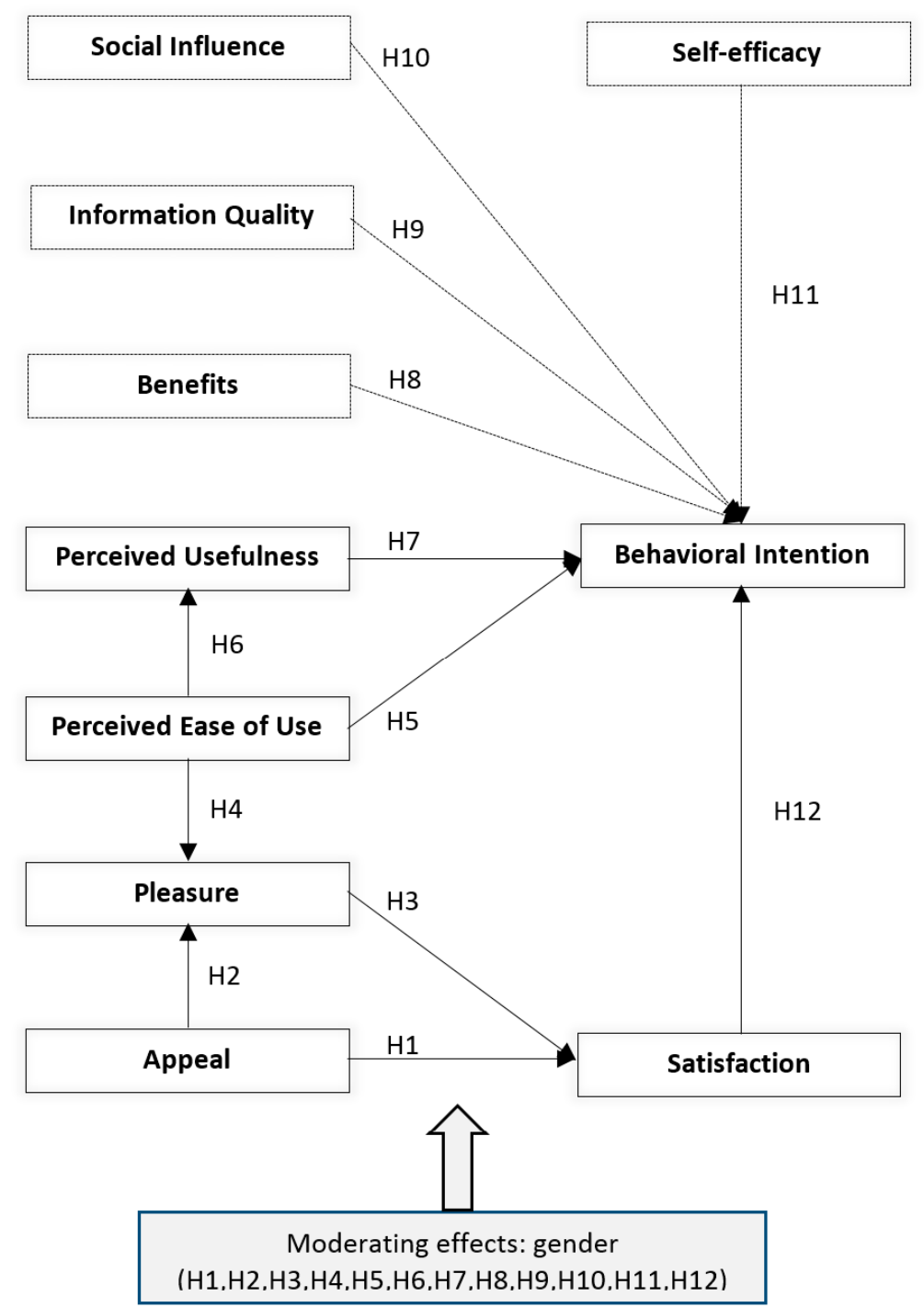

Figure 1. Proposed UX-based e-learning acceptance framework. Constructs and their acronyms: appeal (APP), pleasure (PL), satisfaction (SAT), perceived ease of use (PEoU), perceived usefulness (PU), benefits (BEN), information quality (IQ), social influence (SI), self-efficacy (SE), behavioral intention (BI).

\subsection{Pleasure (PL)}

Hassenzahl [18] defines pleasure as "If people use a particular product and experience desired deviations from expectations, they will be pleased". Eroglu et al. [32] describe it as "the degree to which a person feels good, happy, blessed, or satisfied". The research studies of technology acceptance $[6,33]$ indicate that pleasure has significantly influenced the satisfaction of the related users. In these studies, pleasure has a significant impact on the satisfaction of the users. Eroglu et al. [32] found a positive relationship between pleasure and satisfaction. In another research study of technology acceptance, Wells and Daunt [34] indicated that pleasure has a statistically significant impact on customers satisfaction. Eroglu et al. [32] combined earlier perceptions from the existing research studies and adopted the pleasure construct from the consumers' point of view. Huang [35] also confirmed that for the responses of consumers, pleasure is a key factor. According to Cho et al. [36], when interacting with users, a positive relationship was found between pleasure and satisfaction. As verified by Guo et al. [31], pleasure has a positive significant impact on the students' satisfaction to use the web portal. Therefore, we hypothesize the following: 
Hypothesis 3 (H3). Pleasure has a positive impact on satisfaction to use the e-learning portal.

\subsection{Perceived Ease of Use (PEoU)}

Perceived ease of use is defined by Davis as "the degree to which the prospective user expects the target system to be free of effort" [7]. This construct has been adapted from TAM, which is one of the most extensively used models [7]. Various models have integrated perceived ease of use as an influencing factor of e-learning acceptance [37-39]. In these studies, perceived ease of use has a statistically significant impact on behavioral intention as well as on perceived usefulness. Venkatesh et al. [8,9] have tested effort expectancy in their models UTAUT and UTAUT2 as similar to perceived ease of use and found a significant effect on behavioral intention. Holden and Rada [40] suggested that perceived ease of use is an influential factor for usefulness. Lee et al. [41] reported that usefulness was influenced by perceived ease of use in the e-learning research study. According to Manganari et al. [42], perceived ease of use was a robust factor to predict the pleasure of consumers. They found that perceived ease of use significantly impacts the pleasure at a 99\% confidence level. According to Wang [6], PEoU has a significant effect on the pleasure of the students to use the entertainment-oriented information systems.

Thus, $\mathrm{H} 4, \mathrm{H} 5$ and $\mathrm{H} 6$ are formulated as follows:

Hypothesis 4 (H4). Perceived ease of use has a positive impact on pleasure to use the e-learning portal.

Hypothesis 5 (H5). Perceived ease of use has a positive impact on behavioral intention to use the e-learning portal.

Hypothesis 6 (H6). Perceived ease of use has a positive impact on perceived usefulness to use the e-learning portal.

\subsection{Perceived Usefulness (PU)}

Perceived usefulness can be defined as "the prospective user's subjective probability that using a specific application system will increase his or her job performance within an organizational context" [7]. According to Baby and Kannammal [39], perceived usefulness is an influencing factor that plays a crucial role in the overall impact on the behavioral intention of the students regarding e-learning. The research study [37] also found perceived usefulness as an influential predictor in the e-learning context. Venkatesh et al. [8,9] considered perceived usefulness as performance expectancy in their models UTAUT and UTAUT2. They verified that the behavioral intention has been significantly influenced by performance expectancy. Thus, $\mathrm{H} 7$ is formulated as follows:

Hypothesis 7 (H7). Perceived usefulness has a positive impact on behavioral intention to use the e-learning portal.

\subsection{Benefits (BEN)}

According to Davis [7], the construct benefits can be defined as "the perceptions of people using technology will bring benefits to them". Various researchers have worked on various types of benefits in terms of "enhanced learning", "increased knowledge", "empowerment", "self-reliance", "cost savings", "time savings", and "academic success" [43,44]. When assessing the e-learning system, benefits is a key factor on individual and organizational levels [45]. Hassanzadeh et al. [43] have used benefits as an important factor for the acceptance of the e-learning system. The benefits factor significantly impacts on the intention of the instructors, students, and alumni while using the e-learning system. Holsapple and Lee-Post [44] conducted research on e-learning. Wang et al. [46] have used the Health Belief Model and showed the positive significance of perceived benefit on the users' intention to use the My Health Bank System. Vinitha and Vasantha [47] verified that perceived benefits has a statistically significant effect on the intention of the consumers to 
use e-payment. Lee et al. [48] have investigated the acceptance of Uber ride service. They confirmed that perceived benefits has a significant impact on the intention of users for participating in the Uber ride service. Lwoga [49] has investigated DeLone and McLean's model regarding the successful usage of library technology in Africa. He reported that the net benefits construct is the strongest predictor of the users' intention to use the library system. Thus, H8 is formulated as follows:

Hypothesis 8 (H8). Benefits has a positive impact on behavioral intention to use the e-learning portal.

\subsection{Information Quality (IQ)}

Information quality is defined as "an output quality of contents, accuracy, format and consistency of any information system" [5]. Learners access various types of information when they use any e-learning portal. If the information of the e-learning portal is unsatisfactory, incomplete, old, or inappropriate, then the learner will not use these types of portals again [50]. Information quality may affect the users' behavioral intention to use the e-learning system [51,52]. According to Mohammadi [53], information quality is an important factor of the users' intention. Delone and McLean [54] also proved that information quality significantly impacts the intention of the users. Thus, H9 is formulated as follows:

Hypothesis 9 (H9). Information quality has a positive impact on behavioral intention to use the e-learning portal.

\subsection{Social Influence (SI)}

Social influence is described by Venkatesh et al. [8] as "The consumers perceive that important others (e.g., family and friends) believe that they should use a particular technology". The intention of users in using a specific technology has been influenced by family members, relatives, colleagues, teachers, fellows, and friends [5]. Many research studies confirmed that social influence has a significant impact on the intention of the users; it shapes the intention of an individual when using any new technology [8-10]. So, the current research study attempts to articulate the following hypothesis (H10):

Hypothesis 10 (H10). Social influence has a positive impact on behavioral intention to use the e-learning portal.

\subsection{Self-Efficacy (SE)}

Self-efficacy is described by Bandura [55] as "people's judgments of their capabilities to organize and execute course of action required to attain designated types of performance". According to Pellas [56] and Ahmed et al., [57] self-efficacy has a positive effect on the behavioral intention to use the e-learning system. As per Kelley et al. [58], selfefficacy has a statistically significant impact on use of computer. Isman and Celikli [59] and Venkatesh [10] also indicate that self-efficacy has a positive influence on the users' behavioral intention to use a computer. Thus, H11 is formulated as follows:

Hypothesis 11 (H11). Self-efficacy has a positive impact on behavioral intention to use the e-learning portal.

\subsection{Satisfaction (SAT)}

Hassenzahl [18] described satisfaction as, "If people hold expectations about the outcome of using a particular product and these expectations are confirmed they will feel satisfied". Sanchez-Franco [60] defines satisfaction as "the level of peoples' perception about their necessities, objectives, and desires of the system". Hassanzadeh et al. [43] report in their research study that satisfaction is a positive significant factor for users' intentions toward the use of e-learning services. According to Revythi and Tselios [61], the satisfaction 
construct is an important factor in e-learning technology acceptance research based on the UX. They reported that the satisfaction factor significantly influences the intention of the users using e-learning technology. Chang states that the intention of the users can be enhanced by increasing the satisfaction of the users [62]. As stated by Arain et al. [5], satisfaction is an important factor toward behavioral intention in using e-learning. Thus, H12 is formulated as follows:

Hypothesis 12 (H12). Satisfaction has a positive impact on behavioral intention to use the e-learning portal.

\subsection{Behavioral Intention (BI)}

According to Davis et al. [7], behavioral intention is a "user's willingness to decide to use and continue to use a specific technology". Kim et al. [63] state that "behavioral intention is recognized as a measure of the strength of an individual's willingness to perform a behavior". Altalhi [64] has worked on massive open online courses. During her research, she found that behavioral intention has an essential role in the overall impact of the model; the behavioral intention is a determining factor regarding whether an individual will adopt the specific technology. The higher variance of the model will show a more significant level of behavioral intention for the adoption of e-learning portal by the students. In our proposed framework, behavioral intention is a dependent variable and has been tested accordingly.

\section{Research Methodology}

As per Tabachnik and Fidell [65], the proposed research framework was tested by using a cross-sectional method; i.e., the data have been collected at one specific point in time [5]. The students of Quaid-e-Awam University, Pakistan were the target population of this research study. The quantitative approach was employed by using the questionnaire. The total number of enrolled students of the university was 4000 at the time of the data collection. Out of which, 900 students were given access to use the e-learning portal for two weeks. According to Krejcie and Morgan [66], the minimum sample size is 351 for 4000 populations. Based on that, we administered the questionnaire among these students. The questionnaire was administrated manually as well as online among the students during the fall semester of 2020.

The questionnaire was adapted from various studies $[5,6,9,43,67-74]$, which consists of 48 items with a 5-point Likert scale from 1 to 5 for strongly disagree to strongly agree, respectively. During the preparation of the questionnaire, minor rephrasing was carried out regarding the e-learning context. Briefing about the research objectives was given to the participants before administering the questionnaire [5].

In this study, the students participated voluntarily. In total, 650 responses were collected. The convenience sampling method was adopted for the current research study, as the respondents were easily reachable and ready to participate. After screening, out of 650 questionnaires, 137 questionnaires were excluded due to the large amount of missing values by applying the missing completely at random (MCAR) method [75]. Moreover, few outliers were detected by applying the Mahalanobis $\mathrm{D}^{2}$ method $[76,77]$, which were ignored. Subsequently, 513 questionnaires were considered valid for further analysis. This shows that in each item of the constructs, the data were distributed normally. Moreover, in this research study, multicollinearity was not detected among the independent variables as explained by $[5,76]$.

\section{Results}

According to the demographic information of the participants, $91.62 \%$ were male participants and $8.38 \%$ were female participants. All the students reported that they had 1-3 years of e-learning portal usage experience. All the students were undergraduate students of the university. 


\subsection{Structural Equation Modeling Analysis}

In this research study, structural equation modeling (SEM) was used in two steps for observing the interrelationships among the independent and dependent variables of the proposed research framework, as suggested by $[5,55,76]$. Initially, we assessed the measurement model to analyze the reliability and validity of the constructs and to test the model fitness. Afterward, we assessed the structural model for path analysis between exogenous and endogenous variables [5].

\subsection{Assessment of Measurement Model}

In the measurement model, we assessed the convergent and discriminant validity of the constructs $[5,76]$. We examined the convergent validity of the constructs by factor loading, average variance extracted (AVE), and composite reliability (CR), as recommended by [78]. Hair et al. [76], Holsapple and Lee-Post [44], and Huang [35] recommend that suitable factor loading for further analysis should be higher than 0.5. According to the findings of the current research study, as shown in Table 1, all the factors were loaded with values higher than 0.7 . The AVE values of all the constructs were higher than 0.6 , and the values of $C R$ were higher than 0.8 ; these values are suitable for further analysis, as suggested by [76]. Moreover, the Cronbach's alpha [79] method was also used for measuring the internal consistency of the data. All the reliability coefficients of the constructs were higher than the recommended value (i.e., greater than 0.7) [79]. The data show that the scale has good reliability as well as suitable internal consistency [55,76]. As per the results, the recommended criteria were achieved, so the convergent validity of all the constructs was verified.

Table 1. Measures of convergent validity.

\begin{tabular}{|c|c|c|c|c|}
\hline S\# & Construct & Item Abbreviation & Item & Factor Loading \\
\hline \multirow{7}{*}{1.} & \multicolumn{4}{|c|}{ Appeal $(\alpha=0.919, \mathrm{CR}=0.910, \mathrm{AVE}=0.705)$} \\
\hline & \multirow{6}{*}{$\mathrm{APP}[67]$} & APP1 & The e-learning portal is visually attractive [67]. & 0.847 \\
\hline & & APP2 & The e-learning portal is esthetically appealing [67]. & 0.884 \\
\hline & & APP3 & The look and feel of the e-learning portal is good [67]. & 0.910 \\
\hline & & $\mathrm{APP} 4$ & The e-learning portal is motivating [67]. & 0.944 \\
\hline & & APP5 & The e-learning portal is inviting [67]. & 0.934 \\
\hline & & APP6 & The e-learning portal is desirable [67]. & 0.929 \\
\hline \multirow{7}{*}{2.} & \multicolumn{4}{|c|}{ Pleasure $(\alpha=0.965, \mathrm{CR}=0.932, \mathrm{AVE}=0.753)$} \\
\hline & \multirow{6}{*}{ PL $[6,68]$} & PL1 & I felt pleasure after using the e-learning portal [6]. & 0.781 \\
\hline & & PL2 & I felt joyful after using the e-learning portal [6]. & 0.771 \\
\hline & & PL3 & I felt gratified after using the e-learning portal [6]. & 0.751 \\
\hline & & PL4 & I felt cheerful after using the e-learning portal [68]. & 0.715 \\
\hline & & PL5 & I felt pleased after using the e-learning portal [68]. & 0.744 \\
\hline & & PL6 & I felt happy after using the e-learning portal [68]. & 0.751 \\
\hline \multirow{6}{*}{3.} & \multicolumn{4}{|c|}{ Satisfaction $(\alpha=0.837, \mathrm{CR}=0.824, \mathrm{AVE}=0.607)$} \\
\hline & \multirow{5}{*}{ SAT $[5,69,70]$} & SAT1 & I feel satisfied with using this e-learning portal [69]. & 0.839 \\
\hline & & SAT2 & I feel contented with using this e-learning portal [69]. & 0.880 \\
\hline & & SAT3 & I like this e-learning portal [5]. & 0.865 \\
\hline & & SAT4 & I think this e-learning portal is a good idea [70]. & 0.854 \\
\hline & & SAT5 & My decision to use this e-learning portal is a wise one [70]. & 0.907 \\
\hline
\end{tabular}


Table 1. Cont.

\begin{tabular}{|c|c|c|c|c|}
\hline S\# & Construct & Item Abbreviation & Item & Factor Loading \\
\hline \multirow{6}{*}{4.} & \multicolumn{4}{|c|}{ Perceived Ease of Use $(\alpha=0.900, \mathrm{CR}=0.879, \mathrm{AVE}=0.681)$} \\
\hline & \multirow{5}{*}{ PEoU $[71]$} & PEoU1 & The e-learning portal is easy to use [71]. & 0.883 \\
\hline & & PEoU2 & The e-learning portal is easy to learn [71]. & 0.876 \\
\hline & & PEoU3 & The e-learning portal is easy to access [71]. & 0.873 \\
\hline & & PEoU4 & The e-learning portal is easy to understand [71]. & 0.895 \\
\hline & & PEoU5 & The e-learning portal is convenient [71]. & 0.909 \\
\hline \multirow{6}{*}{5.} & \multicolumn{4}{|c|}{ Perceived Usefulness $(\alpha=0.938, \mathrm{CR}=0.921, \mathrm{AVE}=0.755)$} \\
\hline & \multirow{5}{*}{ PU [71] } & PU1 & The e-learning portal is effective [71]. & 0.916 \\
\hline & & PU2 & The e-learning portal is efficient [71]. & 0.928 \\
\hline & & PU3 & The e-learning portal helps to save time [71]. & 0.904 \\
\hline & & PU4 & The e-learning portal helps to improve my knowledge [71]. & 0.837 \\
\hline & & PU5 & The e-learning portal helps to improve my performance [71]. & 0.857 \\
\hline \multirow{4}{*}{6.} & \multicolumn{4}{|c|}{ Behavioral Intention $(\alpha=0.939, \mathrm{CR}=0.920, \mathrm{AVE}=0.824)$} \\
\hline & \multirow{3}{*}{ BI [9] } & BI1 & I intend to continue using the e-learning portal in the future [9]. & 0.864 \\
\hline & & BI2 & $\begin{array}{l}\text { I will always try to use the e-learning portal in my academic } \\
\text { life [9]. }\end{array}$ & 0.843 \\
\hline & & BI3 & I plan to continue to use the e-learning portal frequently [9]. & 0.860 \\
\hline \multirow{6}{*}{7.} & \multicolumn{4}{|c|}{ Information Quality $(\alpha=0.848, \mathrm{CR}=0.879, \mathrm{AVE}=0.677)$} \\
\hline & \multirow{5}{*}{ IQ [72] } & IQ1 & The e-learning portal has information relevant to my needs [72]. & 0.877 \\
\hline & & IQ2 & Information at the e-learning portal is easy to understand [72]. & 0.904 \\
\hline & & IQ3 & The e-learning portal has reliable information [72]. & 0.886 \\
\hline & & IQ4 & The e-learning portal has sufficient information [72]. & 0.859 \\
\hline & & IQ5 & The e-learning portal has useful information [72]. & 0.755 \\
\hline \multirow{6}{*}{8.} & \multicolumn{4}{|c|}{ Self-Efficacy $(\alpha=0.917, \mathrm{CR}=0.914, \mathrm{AVE}=0.741)$} \\
\hline & \multirow{5}{*}{ SE [73] } & SE1 & $\begin{array}{l}\text { I feel confident in the utilization of the e-learning portal even } \\
\text { when no one is there for assistance [73]. }\end{array}$ & 0.800 \\
\hline & & SE2 & I have sufficient skills to use the e-learning portal [73]. & 0.818 \\
\hline & & SE3 & $\begin{array}{l}\text { I feel confident when using the e-learning portal even if I have } \\
\text { only the online instructions [73]. }\end{array}$ & 0.788 \\
\hline & & SE4 & I feel confident when using the e-learning portal features [73]. & 0.709 \\
\hline & & SE5 & $\begin{array}{l}\text { I feel confident when using the online learning content in the } \\
\text { e-learning portal [73]. }\end{array}$ & 0.854 \\
\hline \multirow{4}{*}{9.} & \multicolumn{4}{|c|}{ Social Influence $(\alpha=0.859, \mathrm{CR}=0.824, \mathrm{AVE}=0.693)$} \\
\hline & \multirow{3}{*}{ SI [9] } & SI1 & $\begin{array}{l}\text { People who are important to me think that I should use the } \\
\text { e-learning portal [9]. }\end{array}$ & 0.864 \\
\hline & & SI2 & $\begin{array}{l}\text { People who influence my behavior think that I should use the } \\
\text { e-learning portal [9]. }\end{array}$ & 0.854 \\
\hline & & SI3 & $\begin{array}{l}\text { People whose opinions that I value prefer that I should use the } \\
\text { e-learning portal [9]. }\end{array}$ & 0.809 \\
\hline
\end{tabular}


Table 1. Cont.

\begin{tabular}{|c|c|c|c|c|}
\hline S\# & Construct & Item Abbreviation & Item & Factor Loading \\
\hline \multirow{6}{*}{10.} & Benefits $(\alpha=$ & $22, \mathrm{CR}=0.904, \mathrm{AVE}=$ & .723) & \\
\hline & \multirow{5}{*}{$\operatorname{BEN}[43,74]$} & BEN1 & $\begin{array}{l}\text { Using the e-learning portal has increased my knowledge and } \\
\text { helped me to be successful in my studies }[43,74] \text {. }\end{array}$ & 0.782 \\
\hline & & BEN2 & $\begin{array}{l}\text { The e-learning portal has helped me to improve my learning } \\
\text { process }[43,74] \text {. }\end{array}$ & 0.788 \\
\hline & & BEN3 & $\begin{array}{l}\text { The e-learning portal makes communication easier with the } \\
\text { instructor and other classmates [74]. }\end{array}$ & 0.776 \\
\hline & & BEN4 & $\begin{array}{l}\text { The e-learning portal saves my time in searching for materials } \\
\text { and cuts down expenditure such as paper cost [74]. }\end{array}$ & 0.861 \\
\hline & & BEN5 & $\begin{array}{l}\text { The e-learning portal has helped me to achieve the learning } \\
\text { goals of my course(s) }[43,74] \text {. }\end{array}$ & 0.847 \\
\hline
\end{tabular}

The discriminant validity was also measured based on variance or covariance difference among the factors along with correlation of the items of the constructs [55,76]. Table 2 shows the correlation coefficients of all the factors. Representing the square root of the AVE, the diagonal values (in bold) are greater than the corresponding correlation coefficients (off-diagonal values) of other factors. Hence, the construct level discriminant validity has been confirmed [43,76].

Table 2. Discriminant validity measures.

\begin{tabular}{|c|c|c|c|c|c|c|c|c|c|c|}
\hline & APP & PL & SAT & PEoU & PU & BI & IQ & SE & SI & BEN \\
\hline $\mathrm{APP}$ & 0.909 & & & & & & & & & \\
\hline PL & 0.344 & 0.752 & & & & & & & & \\
\hline SAT & 0.299 & 0.206 & 0.869 & & & & & & & \\
\hline PEOU & 0.111 & 0.312 & 0.126 & 0.887 & & & & & & \\
\hline PU & -0.013 & 0.054 & -0.012 & 0.184 & 0.899 & & & & & \\
\hline BI & 0.157 & 0.174 & 0.384 & 0.178 & -0.023 & 0.855 & & & & \\
\hline IQ & 0.121 & 0.033 & 0.099 & 0.048 & 0.120 & 0.291 & 0.877 & & & \\
\hline SE & 0.250 & 0.172 & 0.337 & 0.144 & 0.034 & 0.375 & 0.258 & 0.775 & & \\
\hline SI & -0.015 & -0.023 & -0.007 & 0.056 & 0.404 & 0.077 & -0.012 & 0.044 & 0.857 & \\
\hline BEN & 0.163 & 0.200 & 0.260 & 0.114 & 0.069 & 0.253 & 0.132 & 0.233 & 0.091 & 0.804 \\
\hline
\end{tabular}

Table 3 shows the results of the goodness-of-fit test [76]. In the absolute fit measures, the obtained value of $\chi^{2}$ is 1430.435; the degree of freedom is 1019; the ratio of $\chi^{2} / \mathrm{df}$ is 1.404; GFI is 0.9; and RMSEA is 0.037. In the incremental fit measures, the obtained value of NFI is 0.935 and that of CFI is 0.980 . In the parsimony fit measure, the obtained value of AGFI is 0.883 . Table 3 clearly shows that the proposed research framework of the present research study satisfactorily fits the data. 
Table 3. Measures of goodness-of-fit.

\begin{tabular}{cccc}
\hline \multirow{2}{*}{ Measures } & Fit Indices & Obtained Values & Recommended Criteria \\
\hline & $\chi^{2}$ & 1430.435 & - \\
\cline { 2 - 4 } Absolute fit measures & Df & 1019 & - \\
\cline { 2 - 4 } & $\chi^{2} / \mathrm{df}$ & 1.404 & $1<\chi^{2} / \mathrm{df}<3$ \\
\cline { 2 - 4 } & GFI & 0.899 & $\geq 0.90$ \\
\cline { 2 - 4 } Incremental fit measures & RMSEA & 0.028 & $<0.05$ \\
\cline { 2 - 4 } & NFI & 0.935 & $\geq 0.90$ \\
\hline Parsimony fit measures & CFI & 0.980 & $\geq 0.90$ \\
\hline
\end{tabular}

\subsection{Assessment of Structural Model}

In this study, we used the structural model for assessing the path analysis. We tested the relationships of the hypotheses among the independent and the dependent variables in order to assess the influence of the constructs directly or indirectly in the proposed research framework $[5,10,40]$. The data were analyzed by SPSS and AMOS. In Table 4, twelve hypothetical relationships are shown, i.e., H1 (appeal $\rightarrow$ satisfaction), H2 (appeal $\rightarrow$ pleasure), H3 (pleasure $\rightarrow$ satisfaction), H4 (perceived ease of use $\rightarrow$ pleasure), H5 (perceived ease of use $\rightarrow$ behavioral intention), H6 (perceived ease of use $\rightarrow$ perceived usefulness), H7 (perceived usefulness $\rightarrow$ behavioral intention), H8 (benefits $\rightarrow$ behavioral intention), H9 (information quality $\rightarrow$ behavioral intention), H10 (social influence $\rightarrow$ behavioral intention), H11 (self-efficacy $\rightarrow$ behavioral intention), and H12 (satisfaction $\rightarrow$ behavioral intention). All the hypotheses were statistically significant (i.e., $p<0.05$ or $p<0.001)$; hence, they all were supported.

Table 4. Hypotheses testing.

\begin{tabular}{|c|c|c|c|c|}
\hline Hypothesis & Relationship & Critical Ratio or ( $t$ Value) & Supported & Result \\
\hline $\mathrm{H} 1$ & $\mathrm{APP} \rightarrow \mathrm{SAT}$ & 5.473 & Yes *** & Accepted \\
\hline $\mathrm{H} 2$ & $\mathrm{APP} \rightarrow \mathrm{PL}$ & 5.911 & Yes *** & Accepted \\
\hline $\mathrm{H} 3$ & $\mathrm{PL} \rightarrow \mathrm{SAT}$ & 2.336 & Yes * & Accepted \\
\hline $\mathrm{H} 4$ & $\mathrm{PEoU} \rightarrow \mathrm{PL}$ & 5.674 & Yes *** & Accepted \\
\hline H5 & $\mathrm{PEoU} \rightarrow \mathrm{BI}$ & 2.621 & Yes * & Accepted \\
\hline $\mathrm{H} 6$ & $\mathrm{PEoU} \rightarrow \mathrm{PU}$ & 4.114 & Yes $^{* * *}$ & Accepted \\
\hline $\mathrm{H} 7$ & $\mathrm{PU} \rightarrow \mathrm{BI}$ & -2.769 & Yes * & Accepted \\
\hline $\mathrm{H} 8$ & $\mathrm{BEN} \rightarrow \mathrm{BI}$ & 2.217 & Yes* & Accepted \\
\hline $\mathrm{H} 9$ & $\mathrm{IQ} \rightarrow \mathrm{BI}$ & 4.854 & Yes $* * *$ & Accepted \\
\hline $\mathrm{H} 10$ & $\mathrm{SI} \rightarrow \mathrm{BI}$ & 2.373 & Yes * & Accepted \\
\hline H11 & $\mathrm{SE} \rightarrow \mathrm{BI}$ & 3.977 & Yes *** & Accepted \\
\hline $\mathrm{H} 12$ & $\mathrm{SAT} \rightarrow \mathrm{BI}$ & 6.272 & Yes *** & Accepted \\
\hline
\end{tabular}

The proposed UX-based e-learning acceptance framework has been tested. The results showed that the proposed framework explained $27 \%$ of the variance in behavioral intention. Therefore, it is recommended that the proposed constructs of UX (appeal, pleasure, satisfaction), TAM (perceived ease of use, perceived usefulness, behavioral intention), and benefits, information quality, social influence, and self-efficacy may be combined together for getting the maximum variance of the model in order to analyze e-learning acceptance in the context of a higher education institute of a developing country. 


\subsection{Mediating Effects}

Mediating effects were examined for satisfaction: whether satisfaction significantly mediates between appeal and behavioral intention and between pleasure and behavioral intention. Table 5 shows the results of the Sobel test for appeal and pleasure, which are statistically significant $(p<0.001)$. The results in Table 6 show that satisfaction fully mediates between appeal and behavioral intention, while the mediation effect of satisfaction between pleasure and behavioral intention is partial; this shows that the satisfaction as a mediator has statistically significant importance between appeal, pleasure, and behavioral intention.

Table 5. Sobel test.

\begin{tabular}{cccc}
\hline Variables & Test Statistics & Standard Error & $p$-Value \\
\hline Appeal $\rightarrow$ Satisfaction $\rightarrow$ Behavioral Intention & 5.23796080 & 0.02127278 & $0.00000016^{* * *}$ \\
\hline Pleasure $\rightarrow$ Satisfaction $\rightarrow$ Behavioral Intention & 3.81421022 & 0.01713592 & $0.00013662^{* * *}$ \\
\hline
\end{tabular}

Table 6. Mediation analysis.

\begin{tabular}{|c|c|c|c|c|c|c|c|c|c|c|}
\hline \multirow{3}{*}{$\begin{array}{c}\text { Individual } \\
\text { Variable (IV) }\end{array}$} & \multirow{3}{*}{$\begin{array}{l}\text { Mediator } \\
\text { (M) }\end{array}$} & \multirow{3}{*}{$\begin{array}{c}\text { Dependent } \\
\text { Variable (DV) }\end{array}$} & \multicolumn{2}{|c|}{$\mathrm{IV} \rightarrow \mathrm{DV}$} & \multicolumn{2}{|c|}{$\mathrm{IV} \rightarrow \mathrm{M}$} & \multicolumn{4}{|c|}{$\mathrm{IV}+\mathrm{M} \rightarrow \mathrm{DV}$} \\
\hline & & & \multirow{2}{*}{$\beta$} & \multirow{2}{*}{ S.E } & \multirow{2}{*}{$\beta$} & \multirow{2}{*}{ S.E } & \multicolumn{2}{|c|}{ IV } & \multicolumn{2}{|c|}{$\mathbf{M}$} \\
\hline & & & & & & & $\beta$ & S.E & $\beta$ & S.E \\
\hline Appeal (APP) & $\begin{array}{l}\text { Satisfaction } \\
\quad \text { (SAT) }\end{array}$ & $\begin{array}{c}\text { Behavioral } \\
\text { Intention (BI) }\end{array}$ & $0.178^{* * *}$ & 0.048 & $0.294^{* * *}$ & 0.042 & 0.067 & 0.047 & $0.379 * * *$ & 0.048 \\
\hline Pleasure (PL) & $\begin{array}{l}\text { Satisfaction } \\
\quad \text { (SAT) }\end{array}$ & $\begin{array}{l}\text { Behavioral } \\
\text { Intention (BI) }\end{array}$ & $0.159^{* * *}$ & 0.044 & $0.172^{* * *}$ & 0.040 & $0.093^{* * *}$ & 0.043 & $0.380^{* * *}$ & 0.046 \\
\hline
\end{tabular}

\subsection{Influence of Moderator Variable}

In this study, the influence of gender as a moderator has also been investigated for the acceptance of e-learning portal. To discover the gender differences, the respondents of the survey were divided into two groups: male and female. Table 7 shows that the structural weights for the gender (male) are statistically significant for all paths of the model except PU $\rightarrow$ BI and SI $\rightarrow$ BI $(p<0.05)$ where the critical ratios (t-values) are -1.014 and 1.858 , respectively.

However, for other group of gender (female), the structural weights are statistically significant for half of the paths of the model (i.e., APP $\rightarrow$ SAT, APP $\rightarrow$ PL, PEoU $\rightarrow$ PL, $\mathrm{BEN} \rightarrow \mathrm{BI}, \mathrm{SE} \rightarrow \mathrm{BI}, \mathrm{SAT} \rightarrow \mathrm{BI})$. Nevertheless, the structural weights for the combined genders (male and female) are statistically significant for all paths of the model. 
Table 7. Gender moderation effect.

\begin{tabular}{|c|c|c|c|c|c|c|c|c|c|c|c|c|}
\hline \multirow[b]{2}{*}{ 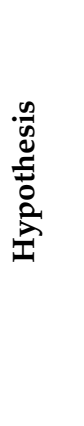 } & \multirow[b]{2}{*}{ 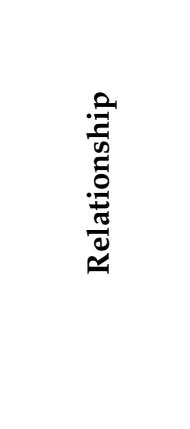 } & \multirow[b]{2}{*}{$\frac{\stackrel{0}{\Xi}}{\stackrel{J}{\pi}}$} & \multicolumn{5}{|c|}{ Male } & \multicolumn{5}{|c|}{ Female } \\
\hline & & & 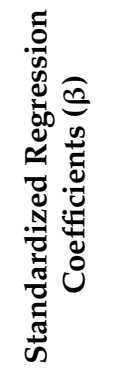 & 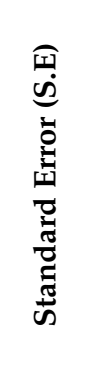 & 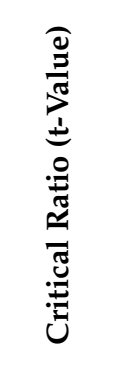 & 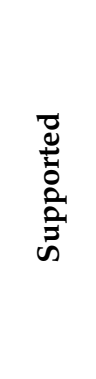 & 节 & 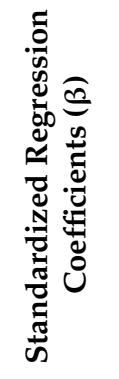 & 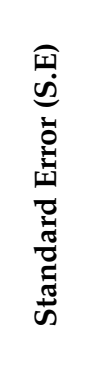 & 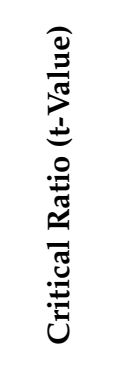 & 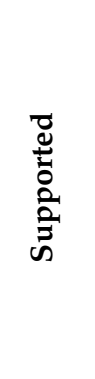 & 节 \\
\hline $\mathrm{H} 1$ & $\mathrm{APP} \rightarrow \mathrm{SAT}$ & 1.185 & 0.28 & 0.045 & 6.155 & $* * *$ & Yes & 0.413 & 0.103 & 4.003 & $* * *$ & Yes \\
\hline $\mathrm{H} 2$ & $\mathrm{APP} \rightarrow \mathrm{PL}$ & 0.590 & 0.355 & 0.048 & 7.332 & $* * *$ & Yes & 0.275 & 0.128 & 2.154 & 0.031 & Yes \\
\hline $\mathrm{H} 3$ & $\mathrm{PL} \rightarrow \mathrm{SAT}$ & 1.014 & 0.188 & 0.043 & 4.391 & $* * *$ & Yes & 0.072 & 0.106 & 0.676 & 0.499 & No \\
\hline $\mathrm{H} 4$ & $\mathrm{PEoU} \rightarrow \mathrm{PL}$ & 0.312 & 0.338 & 0.047 & 7.212 & $* * *$ & Yes & 0.293 & 0.134 & 2.186 & 0.029 & Yes \\
\hline H5 & $\mathrm{PEoU} \rightarrow \mathrm{BI}$ & 1.148 & 0.206 & 0.05 & 4.128 & $* * *$ & Yes & 0.044 & 0.132 & 0.337 & 0.736 & No \\
\hline $\mathrm{H} 6$ & $\mathrm{PEoU} \rightarrow \mathrm{PU}$ & 1.208 & 0.199 & 0.046 & 4.299 & $* * *$ & Yes & 0.046 & 0.118 & 0.385 & 0.700 & No \\
\hline H7 & $\mathrm{PU} \rightarrow \mathrm{BI}$ & 1.028 & -0.052 & 0.051 & -1.014 & 0.311 & No & 0.097 & 0.136 & 0.717 & 0.473 & No \\
\hline H8 & $\mathrm{BEN} \rightarrow \mathrm{BI}$ & 0.687 & 0.229 & 0.049 & 4.662 & $* * *$ & Yes & 0.328 & 0.134 & 2.444 & 0.015 & Yes \\
\hline H9 & $\mathrm{IQ} \rightarrow \mathrm{BI}$ & 0.843 & 0.309 & 0.049 & 6.258 & $* * *$ & Yes & 0.208 & 0.109 & 1.901 & 0.057 & No \\
\hline H10 & $\mathrm{SI} \rightarrow \mathrm{BI}$ & 0.750 & 0.102 & 0.055 & 1.858 & 0.063 & No & -0.031 & 0.169 & -0.183 & 0.855 & No \\
\hline H11 & $\mathrm{SE} \rightarrow \mathrm{BI}$ & 0.799 & 0.412 & 0.054 & 7.644 & $* * *$ & Yes & 0.298 & 0.132 & 2.254 & 0.024 & Yes \\
\hline H12 & $\mathrm{SAT} \rightarrow \mathrm{BI}$ & 0.48 & 0.391 & 0.049 & 7.908 & $* * *$ & Yes & 0.454 & 0.121 & 3.749 & $* * *$ & Yes \\
\hline
\end{tabular}

\section{Discussion and Conclusions}

This research study contributes to the literature of e-learning technology acceptance by combining selected variables from TAM (i.e., perceived ease of use, perceived usefulness, and behavioral intention), UX model (i.e., appeal, pleasure, and satisfaction) and four wellknown constructs from various technology acceptance models (i.e., benefits, information quality, social influence, and self-efficacy), for sustainable higher education, specifically in the context of a higher education institute of a developing country.

In this study, we found that both perceived ease of use and perceived usefulness significantly influence on behavioral intention of the students regarding the acceptance of the e-learning portal. Moreover, perceived ease of use has also a statistically significant influence on perceived usefulness. These results are consistent with previous studies addressing the user acceptance of e-learning technology [37-39,41,53]. Additionally, perceived ease of use also has a positive effect on pleasure. This result is also consistent with previous studies addressing the user acceptance of various technologies such as shopping apps [28] and virtual store layout [36].

Both constructs information quality and benefits have a significant effect on behavioral intention. These findings are consistent with previous studies addressing the user acceptance of e-learning technology $[43,44]$ and other technologies [45-48,50,53,54]. Furthermore, self-efficacy and social influence have also a positive impact on the behavioral intention of the studies regarding the acceptance of the e-learning portal. These results are consistent with earlier works addressing the user acceptance of various technologies $[56,59,61]$ and [8-10], respectively.

The construct appeal from the UX model has significant impacts on both pleasure and satisfaction. These results are in line with [29-31] for appeal to pleasure and in line with $[27,28]$ for appeal to satisfaction. The pleasure also has a statistically significant impact on satisfaction. This result is aligned with [31-34,36]. Similarly, satisfaction significantly 
influences on behavioral intention, thus corroborating with [5,27,43-45,53,54,62]. These results are consistent with previous studies addressing the user acceptance of various technologies, including e-learning. According to these results, the satisfaction construct as a mediator has significant importance between appeal, pleasure, and behavioral intention, indicating it as an integral part of the proposed e-learning framework for enhancing the behavioral intention of the students [5]. The findings revealed that the e-learning portal was perceived by the students as attractive, appealing, pleasurable, and enjoyable, and they were satisfied. These factors can motivate them to engage in e-learning activities. It is recommended that designers, developers, and practitioners should consider these proposed factors when designing and developing an e-learning portal; this can enhance the intention of the students to use it [5].

Moreover, the results showed that the students perceived that the e-learning portal was easy to use, useful, and beneficial, and it had good information quality. Students and educators can readily accept e-learning technology if it helps increase their learning productivity [5]. Furthermore, the findings showed that the students perceived that they felt confident when using the e-learning portal $[56,61]$. They also perceived that there was the influence of their fellows on them for using the e-learning portal $[38,80]$.

The designing and implementation of an e-learning technology has been a challenging and complex task in the context of a higher education institute in a developing country. The proposed framework of our study can explain $27 \%$ of the variance in behavioral intention, suggesting the viability of the framework. Therefore, it is recommended that designers, practitioners, educators, decision-makers, and university administrators should consider these factors of the proposed framework when developing and implementing an e-learning portal for achieving better pedagogical enrichment toward e-learning technology acceptance [5].

\section{Limitations and Future Research}

Although rigorous measures were employed, there are some limitations in this study. Ten factors were investigated in this research study, but we have not included an important factor of TAM i.e., "actual system use", because no existing e-learning portal was available in the university before this study. Moreover, instead of just collecting data at one specific point in time, a longitudinal survey may be conducted in the future. Besides, perception from faculty members may be obtained in future studies. Additionally, to validate and replicate the findings of this research study and improve the generalizability of the research, further research may be carried out, and data may be collected from other universities as well. Furthermore, only one moderator, gender, was used in this study; however age, experience, and qualification can be used in the future. Finally, the total enrolled students of the university were 4000 at the time of the data collection; out of this, only $12.5 \%$ were female students. This is the reason that only a few female students participated in this study, which is a limitation. Nevertheless, $8.38 \%$ of the total participants were female students in this study.

Author Contributions: The authors contributed equally to the conception of the idea, implementing and analyzing the experimental results, and writing the manuscript. All authors have read and agreed to the published version of the manuscript.

Funding: This research received no external funding.

Institutional Review Board Statement: Not applicable.

Informed Consent Statement: Informed consent was obtained from all subjects involved in the study.

Conflicts of Interest: The authors declare no conflict of interest. 


\section{References}

1. Arain, A.A.; Hussain, Z.; Rizvi, W.H.; Vighio, M.S. An analysis of the influence of a mobile learning application on the learning outcomes of higher education students. Univers. Access Inf. Soc. 2017, 17, 325-334. [CrossRef]

2. Soni, V.D. Global Impact of E-learning during COVID 19. SSRN Electron. J. 2020. [CrossRef]

3. Zardari, B.A.; Hussain, Z.; Arain, A.A.; Rizvi, W.H.; Vighio, M.S. QUEST e-learning portal: Applying heuristic evaluation, usability testing and eye tracking. Univers. Access Inf. Soc. 2020, 1-13. [CrossRef]

4. Groth, A.; Haslwanter, D. Efficiency, effectiveness, and satisfaction of responsive mobile tourism websites: A mobile usability study. Inf. Technol. Tour. 2016, 16, 201-228. [CrossRef]

5. Arain, A.A.; Hussain, Z.; Rizvi, W.H.; Vighio, M.S. Extending UTAUT2 toward acceptance of mobile learning in the context of higher education. Univers. Access Inf. Soc. 2019, 18, 659-673. [CrossRef]

6. Verkijika, S.F.; De Wet, L. Understanding word-of-mouth (WOM) intentions of mobile app users: The role of simplicity and emotions during the first interaction. Telemat. Inform. 2019, 41, 218-228. [CrossRef]

7. Davis, F.D. Perceived usefulness, perceived ease of use, and user acceptance of information technology. MIS Q. 1989, 13, 319-340. [CrossRef]

8. Venkatesh, V.; Morris, M.G.; Davis, G.B.; Davis, F.D. User acceptance of information technology: Toward a unified view. MIS Q 2003, 27, 425-478. [CrossRef]

9. Venkatesh, V.; Thong, J.Y.L.; Xu, X. Consumer Acceptance and Use of Information Technology: Extending the Unified Theory of Acceptance and Use of Technology. MIS Q. 2012, 36, 157-178. [CrossRef]

10. Venkatesh, V.; Davis, F.D. A Theoretical Extension of the Technology Acceptance Model: Four Longitudinal Field Studies. Manag. Sci. 2000, 46, 186-204. [CrossRef]

11. Mathieson, K. Predicting User Intentions: Comparing the Technology Acceptance Model with the Theory of Planned Behavior. Inf. Syst. Res. 1991, 2, 173-191. [CrossRef]

12. Davis, F.D.; Bagozzi, R.P.; Warshaw, P.R. User acceptance of computer technology: A comparison of two theoretical models. Manag. Sci. 1989, 35, 982-1003. [CrossRef]

13. International Organization for Standardization, ISO 9241-210:2010(en), Ergonomics of Human-System Interaction-Part 210: Human-Centred Design for Interactive Systems. Available online: https://www.iso.org/obp/ui/\#iso:std:iso:9241:-210:ed-1:en (accessed on 9 May 2021).

14. Norman, D.; Nielsen, J. The Definition of User Experience (UX). Available online: https://www.nngroup.com/articles/definitionuser-experience/ (accessed on 9 May 2021).

15. Hassenzahl, M. The Hedonic/Pragmatic Model of User Experience. Available online: https://www.academia.edu/2880396/ The_hedonic_pragmatic_model_of_user_experience (accessed on 31 May 2021).

16. Harrati, N.; Bouchrika, I.; Tari, A.; Ladjailia, A. Exploring user satisfaction for e-learning systems via usage-based metrics and system usability scale analysis. Comput. Hum. Behav. 2016, 61, 463-471. [CrossRef]

17. Yakit, O.; Ismailova, R. Learning Management System Implementation. Case Study on User Interface Configurations. MANAS J. Eng. 2018, 6, 164-176.

18. Hassenzahl, M. The Thing and I: Understanding the Relationship between User and Product. In Funology; Human-Computer Interaction Series; Blythe, M.A., Overbeeke, K., Monk, A.F., Wright, P.C., Eds.; Springer: Dordrecht, The Netherlands, 2003; Volume 3. [CrossRef]

19. Hornbæk, K.; Hertzum, M. Technology acceptance and user experience: A review of the experiential component in HCI. ACM Trans. Comput.-Hum. Interact. 2017, 24, 1-30. [CrossRef]

20. Boensma, E.C.M. The Use of Gamification and Virtual Reality in e-Learning Tools Used in Preparation for Driving Exams: A Comparative Study. Master's Thesis, University of Twente, Enschede, The Netherlands, 2019.

21. Stern, C. CUBI: A User Experience Model for Project Success (2014). Available online: https://uxmag.com/articles / cubi-a-userexperience-model-for-project-success (accessed on 20 March 2021).

22. Thüring, M.; Mahlke, S. Usability, aesthetics and emotions in human-technology interaction. Int. J. Psychol. 2007, 42, 253-264. [CrossRef]

23. Van Schaik, P.; Ling, J. An integrated model of interaction experience for information retrieval in a Web-based encyclopaedia. Interact. Comput. 2011, 23, 18-32. [CrossRef]

24. Sagnier, C.; Loup-Escande, E.; Lourdeaux, D.; Thouvenin, I.; Valléry, G. User Acceptance of Virtual Reality: An Extended Technology Acceptance Model. Int. J. Hum.-Comput. Interact. 2020, 36, 993-1007. [CrossRef]

25. Montoya-Weiss, M.M.; Voss, G.B.; Grewal, D. Determinants of Online Channel Use and Overall Satisfaction with a Relational, Multichannel Service Provider. J. Acad. Mark. Sci. 2003, 31, 448-458. [CrossRef]

26. Chung, N.; Han, H.; Joun, Y. Tourists' intention to visit a destination: The role of augmented reality (AR) application for a heritage site. Comput. Hum. Behav. 2015, 50, 588-599. [CrossRef]

27. Rodríguez-Torrico, P.; San-Martín, S.; San José-Cabezudo, R. What drives M-shoppers to continue using mobile devices to buy? J. Mark. Theory Pract. 2019, 27, 83-102. [CrossRef]

28. Ch, C.; Gupta, D. Factors influencing customer satisfaction with usage of shopping apps in India. In Proceedings of the 20172 nd IEEE International Conference on Recent Trends in Electronics, Information \& Communication Technology (RTEICT), Bangalore, India, 19-20 May 2017; pp. 1483-1486. 
29. Lee, S.; Ha, S.; Widdows, R. Consumer responses to high-technology products: Product attributes, cognition, and emotions. J. Bus. Res. 2011, 64, 1195-1200. [CrossRef]

30. Chang, S.-H.; Chih, W.-H.; Liou, D.-K.; Hwang, L.-R. The influence of web aesthetics on customers' PAD. Comput. Hum. Behav. 2014, 36, 168-178. [CrossRef]

31. Liu, W.; Guo, F.; Ye, G.; Liang, X. How homepage aesthetic design influences users' satisfaction: Evidence from China. Displays 2016, 42, 25-35. [CrossRef]

32. Eroglu, S.A.; Machleit, K.A.; Davis, L.M. Empirical testing of a model of online store atmospherics and shopper responses. Psychol. Mark. 2003, 20, 139-150. [CrossRef]

33. Nordhoff, S.; van Arem, B.; Happee, R. Conceptual Model to Explain, Predict, and Improve User Acceptance of Driverless Podlike Vehicles. Transp. Res. Rec. J. Transp. Res. Board 2016, 2602, 60-67. [CrossRef]

34. Wells, V.K.; Daunt, K.L. Eduscape: The effects of servicescapes and emotions in academic learning environments. J. Furth. High. Educ. 2015, 40, 486-508. [CrossRef]

35. Huang, M.-H. Modeling virtual exploratory and shopping dynamics: An environmental psychology approach. Inf. Manag. 2003, 41, 39-47. [CrossRef]

36. Cho, W.C.; Lee, K.Y.; Yang, S.B. What makes you feel attached to smartwatches? The stimulus-organism-response (S-O-R) perspectives. Inf. Technol. People 2019, 32, 319-343. [CrossRef]

37. Alhamad, A.Q.M. Acceptance of E-learning among university students in UAE: A practical study. Int. J. Electr. Comput. Eng. 2020, 10,3660-3671. [CrossRef]

38. Al Kurdi, B.; Alshurideh, M.; Salloum, S.A. Investigating a theoretical framework for e-learning technology acceptance. Int. J. Electr. Comput. Eng. 2020, 10, 6484-6496. [CrossRef]

39. Baby, A.; Kannammal, A. Network Path Analysis for developing an enhanced TAM model: A user-centric e-learning perspective. Comput. Hum. Behav. 2020, 107, 106081. [CrossRef]

40. Holden, H.; Rada, R. Understanding the Influence of Perceived Usability and Technology Self-Efficacy on Teachers' Technology Acceptance. J. Res. Technol. Educ. 2011, 43, 343-367. [CrossRef]

41. Lee, Y.-H.; Hsiao, C.; Purnomo, S.H. An empirical examination of individual and system characteristics on enhancing e-learning acceptance. Australas. J. Educ. Technol. 2014, 30, 562-579. [CrossRef]

42. Manganari, E.E.; Siomkos, G.J.; Rigopoulou, I.D.; Vrechopoulos, A.P. Virtual store layout effects on consumer behaviour: Applying an environmental psychology approach in the online travel industry. Internet Res. 2011, 21, 326-346. [CrossRef]

43. Hassanzadeh, A.; Kanaani, F.; Elahi, S. A model for measuring e-learning systems success in universities. Expert Syst. Appl. 2012, 39, 10959-10966. [CrossRef]

44. Holsapple, C.W.; Lee-Post, A. Defining, Assessing, and Promoting E-Learning Success: An Information Systems Perspective. Decis. Sci. J. Innov. Educ. 2006, 4, 67-85. [CrossRef]

45. Petter, S.; Delone, W.; McLean, E. Measuring information systems success: Models, dimensions, measures, and interrelationships. Eur. J. Inf. Syst. 2008, 17, 236-263. [CrossRef]

46. Wang, L.C.; Chuang, H.M.; Chen, Y.S.; Lin, C.K.; Wang, Y.S. A Study on the Acceptance Intention of "My Health Bank" from the Perspective of Health Belief Model. In International Conference on Frontier Computing; Springer: Singapore, 2016; pp. 905-910.

47. Vinitha, K.; Vasantha, S. Determinants of Customer intention to use Digital payment system. J. Adv. Res. Dyn. Control Syst. 2020, $12,168-174$.

48. Lee, Z.W.Y.; Chan, T.K.; Balaji, M.; Chong, A.Y.-L. Why people participate in the sharing economy: An empirical investigation of Uber. Internet Res. 2018, 28, 829-850. [CrossRef]

49. Lwoga, T.E. Measuring the success of library 2.0 technologies in the African context: The suitability of the DeLone and McLean's model. Campus-Wide Inf. Syst. 2013, 30, 288-307. [CrossRef]

50. Zhou, T. Understanding users' initial trust in mobile banking: An elaboration likelihood perspective. Comput. Hum. Behav. 2012, 28, 1518-1525. [CrossRef]

51. Kim, K.; Trimi, S.; Park, H.; Rhee, S. The Impact of CMS Quality on the Outcomes of E-learning Systems in Higher Education: An Empirical Study. Decis. Sci. J. Innov. Educ. 2012, 10, 575-587. [CrossRef]

52. Wang, H.C.; Chiu, Y.F. Assessing e-learning 2.0 system success. Comput. Educ. 2011, 57, 1790-1800. [CrossRef]

53. Mohammadi, H. RETRACTED: Factors affecting the e-learning outcomes: An integration of TAM and IS success model. Telemat. Inform. 2015, 32, 701-719. [CrossRef]

54. Delone, W.H.; McLean, E.R. The DeLone and McLean Model of Information Systems Success: A Ten-Year Update. J. Manag. Inf. Syst. 2003, 19, 9-30. [CrossRef]

55. Bandura, A. Social Foundations of Thought and Action; Prentice Hall: Englewood Cliffs, NJ, USA, 1986; pp. 23-28.

56. Pellas, N. The influence of computer self-efficacy, metacognitive self-regulation and self-esteem on student engagement in online learning programs: Evidence from the virtual world of Second Life. Comput. Hum. Behav. 2014, 35, 157-170. [CrossRef]

57. Ahmad, N.; Umar, N.U.; Kadar, R.; Othman, J. Factors Affecting Students' Acceptance of e-Learning System in Higher Education. J. Comput. Res. Innov. 2020, 5, 54-65. [CrossRef]

58. Kelley, H.; Compeau, D.; Higgins, C. Attribution analysis of computer self-efficacy. In Proceedings of the AMCIS 1999 Proceedings, Milwaukee, WI, USA, 13-15 August 1999; p. 270. 
59. Isman, A.; Celikli, G.E. How Does Student Ability and Self-Efficacy Affect the Usage of Computer Technology? Turk. Online J. Educ. Technol. 2009, 8, 33-38.

60. Sanchez-Franco, M.J. The Moderating Effects of Involvement on the Relationships between Satisfaction, Trust and Commitment in e-Banking. J. Interact. Mark. 2009, 23, 247-258. [CrossRef]

61. Revythi, A.; Tselios, N. Extension of technology acceptance model by using system usability scale to assess behavioral intention to use e-learning. Educ. Inf. Technol. 2019, 24, 2341-2355. [CrossRef]

62. Chang, C. Exploring the determinants of e-learning systems continuance intention in academic libraries. Libr. Manag. 2013, 34, 40-55. [CrossRef]

63. Kim, J.; Ma, Y.J.; Park, J. Are US consumers ready to adopt mobile technology for fashion goods? J. Fash. Mark. Manag. Int. J. 2009, 13, 215-230. [CrossRef]

64. Altalhi, M. Toward a model for acceptance of MOOCs in higher education: The modified UTAUT model for Saudi Arabia. Educ. Inf. Technol. 2021, 26, 1589-1605. [CrossRef]

65. Tabachnik, B.G.; Fidell, L.S. Using Multivariate Statistics, 5th ed.; Allyn \& Bacon: Boston, MA, USA, 2007 ; Volume 5, p. 2007.

66. Krejcie, R.V.; Morgan, D.W. Determining sample size for research activities. Educ. Psychol. Meas. 1970, 30, 607-610. [CrossRef]

67. Hassenzahl, M. The Effect of Perceived Hedonic Quality on Product Appealingness. Int. J. Hum.-Comput. Interact. 2001, 13, 481-499. [CrossRef]

68. Koo, D.-M.; Lee, J.-H. Inter-relationships among dominance, energetic and tense arousal, and pleasure, and differences in their impacts under online vs. offline environment. Comput. Hum. Behav. 2011, 27, 1740-1750. [CrossRef]

69. Zhou, T. Understanding continuance usage of mobile sites. Ind. Manag. Data Syst. 2013, 113, 1286-1299. [CrossRef]

70. Chiu, C.-M.; Sun, S.-Y.; Sun, P.-C.; Ju, T.L. An empirical analysis of the antecedents of web-based learning continuance. Comput. Educ. 2007, 49, 1224-1245. [CrossRef]

71. Mohammadi, H. Investigating users' perspectives on e-learning: An integration of TAM and IS success model. Comput. Hum. Behav. 2015, 45, 359-374. [CrossRef]

72. Kim, H.W.; Xu, Y.; Koh, J. A comparison of online trust building factors between potential customers and repeat customers. J. Assoc. Inf. Syst. 2004, 5, 13. [CrossRef]

73. Salloum, S.A.; Alhamad, A.Q.M.; Al-Emran, M.; Monem, A.A.; Shaalan, K. Exploring Students' Acceptance of E-Learning through the Development of a Comprehensive Technology Acceptance Model. IEEE Access 2019, 7, 128445-128462. [CrossRef]

74. Al-Fraihat, D.; Joy, M.; Masa'Deh, R.; Sinclair, J. Evaluating E-learning systems success: An empirical study. Comput. Hum. Behav. 2020, 102, 67-86. [CrossRef]

75. Cordeiro, C.; Machás, A.; Neves, M.M. A Case Study of a Customer Satisfaction Problem: Bootstrap and Imputation Techniques. In Handbook of Partial Least Squares; Springer: Berlin/Heidelberg, Germany, 2010; pp. 279-287.

76. Hair, J.F.; Black, W.C.; Babin, B.J.; Anderson, R.E.; Tatham, R.L. Multivariate Data Analysis; Pearson Prentice Hall: Upper Saddle River, NJ, USA, 2006.

77. Mahalanobis, P.C. On the Generalized Distance in Statistics; National Institute of Science of India: Bengaluru, India, $1936 ;$ pp. 49-55.

78. Fornell, C.; Larcker, D.F. Evaluating structural equation models with unobservable variables and measurement error. J. Market. Res. 1981, 18, 39-50. [CrossRef]

79. Cronbach, L.J. Coefficient alpha and the internal structure of tests. Psychometrika 1951, 16, 297-334. [CrossRef]

80. Latip, M.S.A.; Noh, I.; Tamrin, M.; Latip, S.N.N.A. Students' Acceptance for e-Learning and the Effects of Self-Efficacy in Malaysia. Int. J. Acad. Res. Bus. Soc. Sci. 2020, 10, 658-674. [CrossRef] 